\title{
The Relationship between Iranian ESP Learners' Translation Ability and Resilience in Reading Comprehension
}

\author{
Fatemeh Malekan \\ Department of English Language Teaching, Islamic Azad University (Shahr-e-Qods Branch), Iran \\ E-mail: malekan.fatemeh@yahoo.com \\ Reza Hajimohammadi (Corresponding author) \\ Technical and Vocational University, Tehran, Iran \\ E-mail: rezalincoln@yahoo.com
}

Received: 25-02-2017

doi:10.7575/aiac.ijels.v.5n.2p.47
Accepted: 22-04-2017

Published: 30-04-2017

\begin{abstract}
The present study was an attempt to investigate the relationship between Iranian ESP Learners' translation ability and resilience in reading comprehension. More specifically, the study aimed to study the resilience cognitive and metacognitive effect on raising L2 reading comprehension through translation. Secondly, the study aimed at pursuing the views and attitudes to find out the extent to which resilience in reading comprehension can predict ESP learners' translation ability. In order to test the null hypotheses, three phases were taken into consideration. First, 120 female adult sophomores majoring at Iran University of Medical Sciences were chosen through a homogeneity test. Second, the participants' translation ability was measured through a translation task and also the validity of this instrument was confirmed by the three professors of the university, and the translation Toolkit Evaluation of UTAH University was used to evaluate the translated works. Next, the participants' reading comprehension ability was determined and finally, Connor and Davidson's (2003) resilience scale was used to find out the level of resilience in reading comprehension of ESP students. The results of data analyses firstly revealed that there was a statistically significant relationship between Iranian ESP learners' translation ability and their resilience in reading comprehension. Secondly, it was revealed that there was a significant positive relationship between Iranian ESP learners' translation ability and their reading comprehension. The findings of the present study could have implications for EFL teachers and learners in the Iranian context.
\end{abstract}

Keywords: ESP, reading comprehension, resilience, translation ability

\section{Introduction}

Reading resilience which is mainly referred to as the capacity to undertake and discuss the complex and demanding work of reading and interpreting literary and rhetorical texts has attracted a lot of attention in the past few decades. As this skill "requires a repertoire of analytical techniques that can be deployed with confidence and flexibility" (Vera, Valenzuela, \& Sotomayor, 2015, p. 693), reading resilience can address the serious problem of a good number of English as a Foreign Language (EFL) learners in reading, comprehending, and translating texts that draw on literary language and techniques and unfamiliar subject matter or present a novel concept (Karimi \& Veisi, 2016).

In dealing with stressful, challenging, and demanding world, students and specially EFL learners should learn how to overcome everyday challenges and adverse situations, through coping strategies, as they are required to obtain academic and social success (Lacina, Bauml, \& Taylor, 2016). One of the challenges of EFL learners in general and English for Special Purposes (ESP) students in particular has been coping with the written texts they receive. Such students need to comprehend texts as their L2 reading tasks and in many cases they have to translate the texts so as to achieve special scientific knowledge and the content the text carries (Shahini, 1988).

In addition, some students face with psychological avoidance in their reading. This may arise from their low proficiency and efficacy in Foreign Language (FL) or some other reasons related to psychological, social and background knowledge in EFL classes (Karimi \& Veisi, 2016). Then, they have to apply some cognitive and meta-cognitive strategies and solutions to overcome to this psychological tension and to get their reading success (Schmidt, 2002). Resilience, as Connor and Davidson (2003) defined, "is a measure of successful stress-coping ability" (p.78). Also, it is a newly-developed psychological construct which can be considered as a personality factor of individual learners. It enables individuals to overcome difficult or traumatic circumstances and grow up to become healthy, educated, and successful learners even in ESP reading proficiency for their professional carrier (Connor \& Davidson, 2003). 
Resilience in ELT may be equivalent to learners' beliefs about themselves, particularly self-efficacy, which contributes to their self-regulated learning and achievement (Vera et al., 2015).

Translation plays a facilitation role for understanding or analytical processing of text and background knowledge recall (Floyd \& Carrell, 1987). Learners have to conceptualize their text reading comprehension like the writer of the text to understand the L2 text. Then, they concentrate to apply their L2 even L1 lexical, syntactic, and semantic and background knowledge due to comprehend the L2 text lexicon, syntactic and information presented in the task (Yanguas, 2009). Also, for the EFL learners, the need to process L2 reading texts makes them naturally apply capabilities of their L1 conceptual processing, by mental translation, from L1 to L2 (Newmark, 1995). They may take a kind of co-conception adjustment through both L1 competences and L2 inputs to avoid misunderstanding during reading. The language threshold hypothesis describes this as reading process transfer from L1 to L2 reading (Cummins, 1979). This collaborative cognitive process is being done in syntactic complex parts of the texts and during cognitive processing in L2. Learners also apply translation strategy on reading as whether to get the meaning of special contexts to overcome the syntactic complexities or because of memory overload (Kern, 1994). Learners' capabilities in application of L1 translation in these occasions can be interpreted as their resilience to overcome probable misunderstanding stresses (Karimi \& Veisi, 2016).

Iranian ESP reading comprehension learners cannot benefit from their resilience because various impediments including their L2 reading proficiency, the negative impacts of shortage in L2 vocabulary, pain taking and time consuming process of L2 reading comprehension, and not being able to decipher the hidden meaning of the text they are covering (Karimi \& Veisi, 2016). Most of the learners lose their concentration on content of the message facing with complex sentences. The learners' psychological conditions are not so clear for EFL teachers and curriculum designers to make analysis of the learners' capabilities and to find their avoidance to go furthermore proficient.

Saffarzadeh (1981) in her introduction to the English books published by SAMT asserted that "developing translation knowledge is a must for ESP learners" (p.3), and Shahini (1988) in his needs assessment for EFL and ESP courses at Shiraz University found that Iranian ESP learners require translation, reading, and writing skills more than other language skills and components in the academic domain. Other scholars (Amiri, 2000, Khoramshahi, 2015) also confirmed the very needs following the needs analyses they did in this regard. Hence, translating the ESP texts is another problem to which Iranian EFL learners are frequently encountered.

The real problem starts when the students have to strive with some technical very long texts during their university life. This may be partially deserved by the fact that instructors do not provide their students with different skills and strategies needed to succeed in their reading comprehension targets (Amiri \& Maftoon, 2010). During such classes, as Huang, Chern, and Lin (2009) discuss, "some more skillful students will obtain the required reading skills by themselves, while other less skillful ones will lose their faith and interest in the course and as a result they appeal to the translation variety of their texts in order to pass the exams" (p.22). Although reading comprehension is a vital part of these exams, students usually do not obtain any instruction on reading skills necessary to read some difficult texts in their teaching life (Huang et al., 2009).

Anthony (1997) reminds that it is not simple where ESP courses end and general English courses begin; many nonexpert ESL instructors use an ESP method in that their syllabi are based on analysis of learner require and their own personal expert knowledge of using English for actual communication. As for a wider definition of ESP, Hutchinson and Waters (1987) theorize, "ESP is an approach to language teaching in which all decisions as to content and method are based on the learner's reason for learning" (p. 19).

In addition, translation once was an important part of English language teaching for a long time, but it has been abandoned since communicative methodologies found their ways to the language classrooms (Kasmer, 1999). Interestingly, although translation was out of favor with English language practitioners, "it has rather stubbornly refused to die in the teaching of languages other than English" (Cook, 2007, p. 83). Outstanding protests to using translation in language teaching can be summarized as follows. First, translation does not assist students develop communication skills. Second, it motivates using L1 instead of L2. Third, translation activities may be appropriate for students who prefer analytical or verbal-linguistic learning strategies. Finally, translation is a hard skill which is not always rewarding (Kavaliauskien \& Kaminskien, 2009).

Translator's ability to read and comprehend an SL text has been argued in the works of many scholars and researchers who have investigated the requirements of a translator (Hatim, 2001; Kasmer, 1999). Translation study researchers recommend the role of the translation ability and personal characteristics such as resilience in the process of reading comprehension (Jones, 2003; Krovetz, 2008; Scheufele \& Iyengar, 2014). It seems necessary to investigate whether translation ability has any relationship with reading comprehension ability of university students.

Based on the purpose of the study and the problems stated above, the following research questions were raised:

1. Is there any statistically significant relationship between Iranian ESP learners' translation ability and their resilience in reading comprehension?

2. Is there any statistically significant relationship between Iranian ESP learners' translation ability and their reading comprehension? 


\section{Method}

The present study seeks to assess the relationship between translation ability and reading comprehension of ESP learners of nursing at Iran medical university. It is hypothesized that ESP learners, when proficient in the basics of English, can process scientific discourse with simplicity if the channel of instruction is through the use of the translation ability, that is, the contribution of the translation ability may facilitate the process of comprehension of specialized texts. In addition, this study is an attempt to detect the extent to which the contribution of the personal characteristics affects the learners' reading comprehension, too. Accordingly, it was an attempt to investigate and determine whether there was any statistically significant relationship between Iranian ESP learners' translation ability and resilience in reading comprehension.

To achieve the purpose of the study, a sample of 120 female sophomore adult students of nursing was selected out of 150 students dealing with their ESP course III $(\mathrm{N}=150)$ through cluster sampling. All the students had passed the ESP courses I and II and dealt with the ESP course III. Their ages varied but all of them were adult ESP learners above 21. The students received the standard Oxford Quick Placement Test (QPT) and those 120 students whose scores fell in the intermediate level of the test (between 24 and 47) were selected as the main participants of the study.

The study employed three steps to test the research hypotheses as follows. First, the cluster sampling method was used to select the participants from the population. Best and Kahn (2006) notes that "cluster sampling is a variation of the simple random sample that is particularly appropriate when the population of interest is infinite, when a list of the members of the population does not exist, or when the geographic distribution of the individuals is widely scattered"'(p.18).

In order to assess the homogeneity of the participants, the standardized Oxford Placement Test (OPT) was administered. The time allotted to take the test was 60 minutes. From among 150 students who were randomly assigned and took part in the testing session, those whose scores were between 24 and 47 (based on the standard scale presented at the closing section of the OPT test booklet) were selected as the main participants of the study.

In the second step, the participants' translation ability was operationally defined through the scores they received on a translation task. An English passage of about 200 words was given to the participants to be translated into Persian. The task was selected from 'Reading Skillfully' by Mirhassani (2003) specifically compiled for the BA students of nursing for their ESP course.

To score the translation of students the Translation Toolkit Evaluation of UTAH University which is a valid and frequently used scale to evaluate the translated works was used.

In the next step, the multiple-choice reading comprehension test including five short passages, each having six questions, was administered to test the participants' comprehension and their ability to make inferences and conclusions based on the reading materials. The total number of questions in this test was 30 .

Finally, the level of resilience in reading comprehension of ESP students was determined through employing Connor and Davidson's resilience scale. Besides, to keep away any misinterpretations, the researcher provided the translated versions of the questionnaire. Subsequently, the researcher collected the data during 4 weeks.

The present study dealt with quantitative and measures of data collection and descriptive analysis, therefore based on Creswell (2013), it was a quantitative research. In the design, the present research enjoyed a correlational research design. The reason is that, based on Hatch and Lazaraton (1991), there was no treatment involved in the study, nor was the study concerned with the leaning process the participants might have gone through as a significant factor. No control was implemented over the effect of independent variables of the study (ESP students' resilience in reading and reading comprehension ability) on the dependent variable (ESP learners' translation ability). None of the variables of the study were manipulated to cause changes, either. What was of paramount importance then was the type and strength of the connection between variables of the study; therefore, a correlational research design was the appropriate design for the accomplishment of the purpose of the study (Field, 2013).

\section{Results and Discussion}

Both descriptive and interferential statistics were employed in this study. In the descriptive analysis Tests of Normality including Kolmogorov-Smirnov and Shapiro-Wilk were used. Also the KR-21 reliability indices for the reading comprehension test, resilience in reading scale and learners' translation ability were calculated. A factor analysis through the varimax rotation was also run to probe the construct validity of the resilience in reading scale.

In the inferential analysis, correlation coefficients were calculated through Pearson's correlation coefficient formula to answer the first and second research questions. The first research question was an attempt to find out whether there was any statistically significant relationship between Iranian ESP learners' translation ability and their resilience in reading comprehension. A Pearson correlation was run to probe the first research question. The results of the Pearson correlation $(\mathrm{r}(118)=.74, \mathrm{p}=.000$, representing a large effect size indicated that there was a significant relationship between Iranian ESP learners' translation ability and their resilience in reading comprehension. Thus, the first nullhypotheses as "there is no statistically significant relationship between Iranian ESP learners' translation ability and their resilience in reading comprehension", was rejected. 


\begin{tabular}{llc}
\hline & & Translation \\
\hline \multirow{3}{*}{ Resilience } & Pearson Correlation & $.742^{* *}$ \\
& Sig. (2-tailed) & .000 \\
& $\mathrm{~N}$ & 120 \\
\hline
\end{tabular}

**. Correlation is significant at the 0.01 level (2-tailed).

The second research question was an attempt to see if there was any statistically significant relationship between Iranian ESP learners' translation ability and their reading comprehension.

To answer this question a Pearson correlation was run and the results of the Pearson correlation $(\mathrm{r}(118)=.83, \mathrm{p}=.000$, representing a large effect size) indicated that there was a significant relationship between Iranian ESP learners' translation ability and their reading comprehension. Thus, the second null-hypotheses as "there is no statistically significant relationship between Iranian ESP learners' translation ability and their reading comprehension", was rejected.

Table 2. Pearson Correlation; Translation with Reading Comprehension

\begin{tabular}{llc}
\hline & & Translation \\
\hline Reading Comprehension & Pearson Correlation & $.839^{* *}$ \\
& Sig. (2-tailed) & .000 \\
\hline$* *$ C & $\mathrm{N}$ & 120 \\
\hline
\end{tabular}

**. Correlation is significant at the 0.01 level (2-tailed).

The present study demonstrated that resilience in reading can predict translation ability of ESP learners. EFL learners in general, and ESP learners of nursing in particular need to know native like vocabularies, phrasal verbs, grammatical points, preferences, dictions, connections, organizations, task recognition and the like for a native like writing performance (Ellis, 2009). Therefore, according to the results of the present study, some implications for teaching and learning resilience in reading and reading comprehension strategies and their effect on translation ability of ESP learners can be suggested:

Resilience in reading and its related strategies could be employed by second language teachers to make the learners more aware of what they are dealing with while translating texts from English to Persian. The assumption is that resilience in reading comprehension facilitates translation development (Kiraly, 2015), and learners must pay attention to the specific strategies features which could enrich their translation ability and focus on the fact that well-organized translation requires full understanding of the ESP texts. Considering the differences existing between the target like forms and those of the first language while translating might help the learners come up with more to-the-point and comprehensive translations (Bernard, 2014). This could be energized via employing resilience in reading and its related strategies.

These findings can take support from some other studies such as Masten (2001), Cook (2007), Krovetz (2008), Göpferich, (2009), Eser (2014), Masten (2014), Bennett (2016), and Li (2016) in terms of the relationship between ESP learners' translation ability and their resilience in reading comprehension. The findings also can take support from some other studies (Avand, 2009; Kern, 1994; Kiraly (1995, 2000, 2014, and 2016; Montafej \& Nemati, 2014; Popovic, 2013; Rostami, 2013) concerning the relationship between Iranian ESP learners' translation ability and their reading comprehension.

\section{Conclusion}

The results of data analyses firstly revealed that there was statistically significant relationship between Iranian ESP learners' translation ability and their resilience in reading comprehension. Secondly, it was revealed that there was a significant positive relationship between Iranian ESP learners' translation ability and their reading comprehension.

Monitoring the translated materials and presenting a dynamic concentration on what is being developed is also possible through employing resilience in reading instruction and paying attention to meaningful structures in learner translations (Eser, 2015). This could be done through a kind of cognitive comparison which has been seen as one of the crucial processes in language acquisition (Farrell, 2014). 
English teachers could use resilience in reading and its related language instruction and techniques such as finding relations, categorizing the information, brain storming, redeveloping subcategories mentioned in the text, analyzing the text content, focusing major and minor ideas (Kamali \& Fahim, 2011) in their classes to facilitate learning for the learners. By this way, the classroom interactions could be enriched and would help subsequent L2 development of the learners.

EFL learners could use the strategies and techniques of resilience in reading and reading comprehension to improve their abilities in the second language translation. To do so, they can rely on the resilience enriching techniques such as finding relations between the concepts to be mentioned in a text, categorizing the information presented and understanding the meaning of required terms and vocabularies, extracting subcategories, focusing on major and minor ideas, and concentrating on the specific grammatical points and structures used in the text ideas (Kamali \& Fahim, 2011; Karimi \& Veisi, 2016; Kendeou, et al., 2005). Employing resilience in reading techniques, EFL learners can develop the techniques required for the proper text analysis and accordingly they might present good translations. They also can rely on the strategies which are more conducive to better second language translation (Montafej \& Nemati, 2014). In case the EFL learners get familiar with the concepts of resilience in reading and reading strategies as well as critical thinking before translating, they will learn how to start their translation, develop the first draft, and revise and polish their translations.

Materials developers and syllable designers in the ELT domain also could employ the findings of the present study and those of the similar ones to present tasks in which learners' awareness toward second language reading and resilience in reading comprehension are enhanced. Such tasks may help the learners move towards self-correction, autonomy, and meaningful learning as well.

\section{References}

Amiri, M. (2000). A study on the English language programs at B.A. level at Tehran universities. Master's thesis, Allameh Tabatabai University, Tehran, Iran.

Amiri, M., \& Maftoon, P. (2010). Awareness of reading strategies among Iranian high school students. In Proceedings of EDULEARN10 Conference (pp. 6782-6791).

Anthony, E. M. (1997). Approach, method, and technique. ELT Journal, 2(2), 63-43.

Avand, A. Q. (2009). Using translation and reading comprehension of ESP learners. Asian ESP Journal, 5(1), 44-60.

Bennett, K. (2016). Jaroslav Spirk, Censorship, indirect translations and non-translation: the (fateful) adventures of Czech literature in 20th-century Portugal. The Translator, 22(1), 120-122.

Bernard, B. (2014). Resiliency: What have we learned? San Francisco, CA: WestEd Publication.

Best, J. W., \& Kahn, J.W. (2006). Research in education. London: Pearson/Allyn and Bacon.

Connor, K. M., \& Davidson, J. R. T. (2003). Development of a new resilience scale: The Connor-Davidson resilience scale (CD-RISC). Depression and Anxiety, 18, 76-82.

Cook, G. (2007). A thing of the future: translation in language learning. International Journal of Applied Linguistics, 17(3), 396-401.

Creswell, J. W. (2013). Research design: Qualitative, quantitative, and mixed methods approaches. New York: Sage publications.

Cummins, J. (1979). Linguistic interdependence and the educational development of bilingual children. Review of educational research, 49(2), 222-251.

Ellis, R. (2009). The differential effects of three types of task planning on the fluency, complexity, and accuracy in L2 oral production. Applied Linguistics, 30(4), 474-509.

Eser, O. (2014). Setting learning objectives in translation at the department of foreign language teaching through the concept of competence. Electronic Turkish Studies, 9(5), 21-30.

Eser, O. (2015). A model of translator's competence from an educational perspective. International Journal of Comparative Literature \& Translation Studies, 3(1), 5-15.

Farrell, T. S. (2014). Promoting teacher reflection in second language education: A framework for TESOL professionals. London: Routledge.

Floyd, P., \& Carrell, P. L. (1987). Effects on ESL reading of teaching cultural content schemata. Language learning, 37(1), 89-108.

Göpferich, S. (2009). Towards a model of translation competence and its acquisition: the longitudinal study TransComp. Translation, 1(2), 11-37.

Hatch, E. M., \& Lazaraton, A. (1991). The research manual: Design and statistics for applied linguistics. New York: Newbury House Publishers.

Hatim, B. (2001). Teaching and researching translation. Harlow: Pearson Education Limited.

Huang, H. C., Chern, C. L., \& Lin, C. C. (2009). EFL learners' use of online reading strategies and comprehension of texts: An exploratory study. Computers \& Education, 52(1), 13-26. 
Hutchinson, T., \& Waters, A. (1987). English for specific purposes. Cambridge: Cambridge University Press.

Jones, J. L. (2003). I build resiliency: The role of the school media specialist. School Libraries Worldwide, 9 (2), 90-99.

Kamali, Z., \& Fahim, M. (2011). The relationship between critical thinking ability of Iranian EFL learners and their resilience level facing unfamiliar vocabulary items in reading. Journal of Language Teaching and Research, 2(1), 104111.

Karimi, L., \& Veisi, F. (2016). The impact of teaching critical thinking skills on reading comprehension of Iranian intermediate EFL learners. Theory and Practice in Language Studies, 6(9), 1869-1876.

Kasmer, W. (1999). The role of translation in EFL/ESL classroom. UK: University of Birmingham.

Kavaliauskien, Ã, G., \& Kaminskien, Ã, L. (2007). Translation as a learning tool in English for specific purposes. Retrieved 2009, from $V A ; \ddot{A} \AA$ Vilniaus universiteto leidykla: http://www.leidykla.eu/fileadmin.pdf

Kendeou, P., Lynch, J. S., van den Broek, P., Espin, C., White, M., \& Kremer, K. E. (2005).Developing successful readers: Building early narrative comprehension skills through television viewing and listening. Early Childhood Education Journal, 33, 91-98.

Kern, R.G. (1994). The role of mental translation in second language reading. Studies in Second Language Acquisition, 16(4), 441-461.

Khoramshahi, E. (2015). A needs analysis study on the curriculum of simultaneous interpretation major in appliedscientific comprehensive university. MA Thesis. Islamic Azad University, Saveh-Science and Research Branch. Saveh, Iran.

Kiraly, D. (1995). Pathways to translation, pedagogy and process. Kent, OH: The Kent State University Press.

Kiraly, D. (2000). A social constructivist approach to translator education: Empowerment from theory to practice. Manchester: St. Jerome Publishing.

Kiraly, D. (2014). A social constructivist approach to translator education: Empowerment from theory to practice (2nd. ed.). London: Routledge.

Kiraly, D. C. (2015). Occasioning translator competence: Moving beyond social constructivism toward a postmodern alternative to instructionism. Translation and Interpreting Studies, 10(1), 8-32.

Krovetz, M. L. (2008). Fostering resilience: Expecting all students to use their minds and hearts as well (2nd ed.). Thousand Oaks: Corwin Press.

Lacina, J., Bauml, M., \& Taylor, E. R. (2016). Promoting resilience through read-alouds. YC Young Children, 71(2), 16-27.

Li, R. E. N. (2016). Teaching model of Japanese translation under perspective of cognitive linguistics translation theory. Studies in Literature and Language, 11(4), 21-35.

Masten, A. S. (2001). Ordinary magic: Resilience processes in development. The American Psychologist, 56, $227-238$. doi:10.1037/0003-066X.56.3.227

Masten, A. S. (2014). Invited commentary: Resilience and positive youth development frameworks in developmental science. Journal of Youth and Adolescence, 43(6), 1018-1024.

Masten, A. S., \& Obradović, J. (2006). Competence and resilience in development. Annals of the New York Academy of Sciences, 1094(1), 13-27. doi:10.1196/annals.1376.003.

Mirhassani, A. (2003). Theories, approaches \& methods in teaching English as a foreign language. Tehran: Zabankade Montafej, J., \& Nemati, A. (2014). Investigating translation competence and its sub-competencies through different viewpoints and proposing PACTE group model as the best one. International Journal of Language Learning and Applied Linguistics World (IJLLALW), 5(1), 16-27.

Newmark, P. (1995). Truth and culture in translation. Lebende Sprachen, 40(2), 49-51.

Popovic, R. (2013). The place of translation in language teaching. Retrieved from http://www.sueleatherassociates.com/pdfs/Article_translationinlanguageteachin g.pdf

Rostami, F. (2013). On the Relationship between Literary Translation Ability and Literary Translation Intelligence: A Validation Approach (MA dissertation), Imam Reza International University, Mashhad.

Saffarzadeh, T. (1981). An introduction to the English books published by SAMT. Tehran: SAMT Publications.

Schmidt, R. (2002). Awareness and second language acquisition. Annual Review of Applied Linguistics, 13, $206-226$.

Scheufele, D.A., \& Iyengar, S. (2014). The state of framing research: a call for new directions. In K, Kenski \&, K. H, Jamieson (Eds.), The Oxford handbook of political communication theories. New York: Oxford University Press.

Shahini, G. H. (1988). A needs assessment for EFL courses at Shiraz University. (M.A. thesis). Shiraz University, Shiraz, Iran.

Vera, G. G., Valenzuela, J. P., \& Sotomayor, C. (2015). Against all odds: Outstanding reading performance among Chilean youth in vulnerable conditions. Comparative Education Review, 59(4), 693-716

Yanguas, I. (2009). Multimedia glosses and their effect on L2 text comprehension and vocabulary learning. Language Learning \& Technology, 13(2), 48-67. 